\title{
Correction to: Generalized rectifiability of measures and the identification problem
}

\author{
Matthew Badger ${ }^{1}$
}

Published online: 24 April 2019

(c) Springer Nature Switzerland AG 2019

\section{Correction to: Complex Analysis and its Synergies https://doi.org/10.1007/s40627-019-0027-3}

The article, "Generalized rectifiability of measures and the identification problem ", written by Matthew Badger was originally published electronically on the publisher's internet portal (currently SpringerLink) on March 6, 2019, as open access, with "() The Author(s)"; instead, it should be "() Springer Nature Switzerland AG" and the article is forthwith distributed under the terms of copyright.

The original article has been corrected.

Publisher's Note Springer Nature remains neutral with regard to jurisdictional claims in published maps and institutional affiliations.

The online version of the original article can be found under doi: https://doi.org/10.1007/s40627-019-0027-3.

Matthew Badger

matthew.badger@uconn.edu

1 Department of Mathematics, University of Connecticut, Storrs, CT 06269-3009, USA 